\title{
The Influence of Financial Culture on SME's Financial Performance
}

\author{
Riad Makdissi ${ }^{*}$, Anita Nehme ${ }^{2}$, Rachelle Chahine ${ }^{1}$ \\ ${ }^{1}$ Faculty of Economics and Business Administration, Lebanese University, Tripoli, Lebanon \\ ${ }^{2}$ Business Management and Administration Department, University of Balamand, Koura, Lebanon \\ Email: ^riad.makdissi@ul.edu.lb, anita.nehme@balamand.edu.lb,rachellechahin@gmail.com
}

How to cite this paper: Makdissi, R., Nehme, A., \& Chahine, R. (2020). The Influence of Financial Culture on SME's Financial Performance. Journal of Financial Risk Management, 9, 1-22. https://doi.org/10.4236/jfrm.2020.91001

Received: January 28, 2020

Accepted: February 17, 2020

Published: February 20, 2020

Copyright $\odot 2020$ by author(s) and Scientific Research Publishing Inc. This work is licensed under the Creative Commons Attribution International License (CC BY 4.0).

http://creativecommons.org/licenses/by/4.0/

(c) (i) Open Access

\begin{abstract}
Entrepreneurs are faced with complex financial decisions to turn their businesses around. They make financial decisions in the form of savings, investment and retirement planning, which makes financial culture crucial in business financing decisions and subsequent performance. Decisions made by SME owners need to be madse with a certain level of expertise, which requires financial knowledge, behaviors and attitudes that will enhance the financial performance of the business. The purpose of this research is to know the influence of financial culture on the SMEs' financial performance in Lebanon. The survey made it possible to deduce the relationship between the financial culture and the financial performance.
\end{abstract}

\section{Keywords}

SMEs, Financial Culture, Financial Performance

\section{Introduction}

Both developed and developing economies rely on SMEs to play a key role in triggering and sustaining economic growth and development. SMEs have shown a very broad contribution to job creation, wealth, development and productivity growth, things which are vital for all economies (Karadag, 2016).

Perceived as an instrument of economic growth and in view of their flexibility in adapting to the conditions of the business environment, SMEs are called upon to improve their competitiveness and performance if they are to play a significant role in the markets (Matejun, 2014).

However, with the advent of new technologies and globalization, the economic and social environment in which people make financial decisions is developing and this change is being pursued by a constant evolution of technology 
leading to rapid growth and the sophistication of financial systems (Lusardi \& Mitchell, 2011). So among the obstacles confronting the growth in performance of small and medium enterprises is the lack of knowledge, skills, attitudes and awareness needed to manage their organization's finances (Wang, 2016). Joo and Grable (2004) stated that the reasons why business people make inappropriate, inadequate and ineffective financial decisions are due to the lack of personal financial knowledge and of time to learn about personal financial management, the complexity of financial transactions, as well as the wide variety of financial product and service choices.

The low level of financial culture can hinder the level of performance of SMEs. This calls for the intervention of financial culture in order to train SMEs in the use of available means of access to financial services to increase their profitability, reduce costs related to commercial activities and thus achieve a healthy financial performance (Tidor, Gelmereanu, Baru, \& Morar, 2012).

Financial culture refers to the knowledge of money and financial products that people can apply to financial choices in order to make informed decisions about managing their finances (Basu, 2005). In parallel, there are definitions of financial culture specifically for managers and business people. A financially literate owner-manager of an SME has been defined as a person who knows the most appropriate financing decisions for business performance at different stages of company growth; knows where to obtain the most appropriate products and services and confidently interacts with suppliers of these products and services (Blackburn, Hart, \& Wainwright, 2013). Entrepreneurs are faced with complex financial decisions to turn their businesses around, they make financial decisions in the form of savings, investment and retirement planning, which makes financial culture crucial in business financing decisions and subsequent performance. Decisions made by SME owners need to be made with a certain level of expertise, which requires financial culture knowledge, behaviors and attitudes that will enhance the financial performance of the business (Freiling \& Harima, 2019).

Indeed, various specialists have stressed the need for SMEs' financial culture:

- The need for financial culture among entrepreneurs and business owners, which has become a topic of interest to both developed and developing economies as a result of this change in the financial environment (Hilgert, Hogarth, \& Beverly, 2003).

- Financial culture is important for the profitability and growth performance of SMEs, which have shown that a lack of financial culture causes business failures around the world (Schmidt, Niwaha, \& Tumuramye, 2016).

- Financial education is one of the factors that have a positive impact on the growth of SMEs, as entrepreneurs with sufficient financial culture are better able to adapt their businesses to changing business environments (King \& McGrath, 2002).

- Financial culture helps provide entrepreneurs with the financial knowledge needed to budget households, set up savings plans and acquire financial 
knowledge and skills to achieve their financial goals (Akhtar \& Liu, 2018).

Similarly, various studies have been conducted reflecting the importance of financial culture on the performance in terms of SMEs' profitability and growth, and have shown that the lack of financial culture causes business failures worldwide (Schmidt, Niwaha, \& Tumuramye, 2016).

(Kofi, Nunoo, Asamoah, Yaw, \& Osei-Asare, 2012), in a study examining the influence of financial culture on SMEs, found that financial culture is essential to stimulate SME sectors. The results of the study showed that financial culture has a positive effect on SMEs' performance. SMEs with financial skills can save more money and get a better manage risk.

Our study's general objective is to examine the financial culture's effect on SMEs' financial performance in Lebanon. We then can ask the following question:

What is the influence of financial culture on SMEs' financial performance in Lebanon?

For the conduct of our research work, we proceeded to a combination between the descriptive method and a survey as an application. We focused on the literature review on the financial culture from different angles, from concept, to importance, ending by culture limitations. We have used the hypothetico deductive method which is designed to test the proposed hypothesis. In addition, and as a sample, we have selected employees and managers of SMEs in various regions of Lebanon.

\section{Literature Review}

Financial culture is a key life skill and is a political priority in some countries. Tightening social protection systems, demographic changes and the sophistication and expansion of financial services all contribute to highlighting the importance of financial culture (Kimiyaghalam \& Safari, 2015).

In this section, we develop the definition of financial culture, its importance and its limitations.

\subsection{The Concept of Financial Culture}

The aim of financial education is not to transform agents into speculators using the most advanced financial techniques, but rather to make the majority of them aware of their society, always being able to make the right choices regarding financial matters at different stages of their lives. Many have defined financial culture and highlighted its importance. In what follows, we outline the concept of financial culture.

\subsubsection{Definition of Financial Culture}

Financial education teaches us the best ways to manage our money according to our life motives, as well as the financial and economic contexts. For the time being, it is playing an important role in conjunction with the recession in many Western economies. 
However, the school system does not value the latter type of education, so most of us may never have heard of it or learned what we need to know to be in control of our financial lives (Aren \& Aydemir, 2014).

According to a definition established by the Council of the Organisation for Economic Co-operation and Development (OECD), financial education is the process by which consumers and investors seeking to improve their knowledge of financial concepts, products and risks acquire, through objective education, information or advice, the confidence and skills necessary to become as aware as possible of financial risks and opportunities and to make informed choices, all while knowing the causes and finding or knowing how to obtain financial assistance, as well as to take other good initiatives for a better financial well-being.

Financial culture is not satisfied with the mere provision of financial advice and information, but tends to promote it in financial matters, based on appropriate financial information and instruction. Financial culture should be provided in an equitable and unbiased manner, with coordinated and effectively developed programs (Stolper \& Walter, 2017).

In addition, financial culture can be defined as the understanding and knowledge of financial principles needed to make financial decisions and products that affect financial well-being (Basu, 2005). This includes the ability to take effective action on financial decisions (Worthington Jr., Lavelock, Witvliet, Rye, Tsang, \& Toussaint, 2015).

\subsubsection{The Objective of Financial Culture}

The rationale for financial education is not solely limited to eliminating the totality of financial problems that might simply be beyond individual responsibility, nor is it limited to judging consumer choices. Financial education attempts rather to provide individuals with the skills and knowledge, enabling them to make good financial decisions. This can only be achieved through the ability to determine the right credits and investments (Calcagno \& Monticone, 2013).

However, financial education's qualities are innumerable, both for the individual and for society as a whole. In this way, it will be easier for everyone to optimize the management of their own personal finances, anticipating the unexpected. Therefore, reducing the risks of financial exclusion will certainly help to consolidate the integration of the poorest people (Shukla \& Kukreja, 2014).

The gradual development of financial innovation has made financial education a prerequisite for any advice and sale of financial products more than ever.

Therefore, financial education aims to provide everyone with a background of skills and knowledge, enabling them to make relevant choices in the financial field, i.e. to be able to analyze the types of investments and credits most appropriate for them. On the other hand, the main goal is to enable everyone to access the fundamental financial tool that is the bank account (Lusardi, 2019).

Financial culture tends to be beneficial for the whole society at a later stage. As a result, individuals will optimize the management of their capital more easily, anticipating financially unexpected situations. In addition, reducing the risks of 
financial exclusion will consolidate the integration of the most disadvantaged people. Finally, the more thoughtful saving and liquidity provision behavior in financial markets are favorable, the better the economy will improve.

\subsection{The Importance of Financial Culture}

Understanding basic financial concepts is seen as an integral part of financial education aimed at establishing good practices in the day-to-day stewardship of all those who might make decisions related to money and finances.

\subsubsection{The Need to Develop the Public's Financial Culture}

A study conducted by the OECD in 2005 (OECD, 2005) as part of the Financial Education Project confirms that only a few countries have conducted systematic surveys. Thus, the study unanimously concluded that there is a deficit in individual financial culture around the world. What worries us more is that, generally speaking, individuals are not the only ones who are unaware of the financial field, or rather do not understand it sufficiently, but they often believe they know about it very well, even more than is the case at present. We should also add the developments in the social world and in financial products, making in-depth financial education of the general public more and more urgent.

Factors that reinforce the importance of financial culture are:

- The transfer of financial responsibility to the citizen

It could be said that the citizen is gradually moving towards becoming a citizen worthy of taking risks and responsibilities associated with financial decisions, particularly with regard to social protection. Today, the guarantees enjoyed by an insured citizen are considered less strong than in the past, making him or her resort to individual savings in order to fill the gaps left by the lack of collective guarantees.

- The gradual complexity of financial products and services

As financial products become more and more complex, the decisions consumers have to make about financial products are getting extremely difficult, requiring them to acquire a solid knowledge of financial products. Consumers generally have a wide variety of financial instruments at their disposal, offering a range of options in terms of interest rates, fees, maturities, etc. Moreover, the importance and quality of some of these financial products, such as life insurance policies, in meeting consumer needs is difficult to assess, as consumers rarely purchase such products, their purchases and uses of these products often being separated by long time intervals.

- The multitude of financial products and providers

The deregulation of capital markets and the cost reduction made possible by the development of new information and telecommunications technologies have all encouraged a proliferation of new products meeting very specific market needs. The Internet has also made it possible to obtain more information about investment and credit products and their availability.

- Birth boom and longer life expectancy 
After the Second World War, many OECD countries experienced a demographic boom in terms of births. Those born at that time will retire in about five to ten years. A few in the population delayed having children or probably chose to have fewer or no children, reducing the number of people in the post-boom generation. As a result, retired workers from the baby boom generation will create a smaller number of younger workers to finance them. This situation is increasingly aggravated by longer life expectancy, which means that these many retirees may enjoy their retirement more than those of past generations, thus needing to be funded for longer. That being said, public pay-as-you-go pension schemes in OECD countries will have to bear the heavy burden of their aging populations.

- The evolution of pension schemes

Pension schemes in OECD member countries often tend to move from defined benefit to defined contribution schemes. In the first case, the pension recipient defines an amount as retirement income; in the second case, it is the level of contributions that is set, with retirement income thus depending on the investment decisions and contribution rates made by the individual during his or her working life. As a result, more of the risk that was previously associated with making provisions for retirement has shifted from the claimant to the worker. However, an increasing number of retired people will in the future depend on the income provided by defined contribution pension schemes.

- Deficient financial culture

An overview of financial culture surveys in twelve OECD member countries revealed that consumers' financial culture is low. It could be said that the level of financial culture is particularly low in certain segments of the population, such as minorities, the less educated and those at the lower end of the income scale.

\subsubsection{Financial Culture's Benefits to the Economy}

- Financial education tends to benefit all consumers, regardless of age or income. It provides the basic tools necessary for young people entering the labor market to manage their savings and budget, enabling them to keep their debts and expenses under control.

- In addition, financial education can help families acquire the discipline they need to save and buy a home or to finance their children's education. It can also help older workers to ensure that they save enough for a comfortable retirement, by providing them with the know-how and information they need to make wise investments, both in terms of their pension plan and their personal savings plan.

- Financial education can also help low-income people make the most of what they can save. This education can also help them to circumvent the high costs of financial transactions through non-financial institutions, such as cheque-cashing services. For consumers with money to invest, it can help them better understand basic financial concepts such as the need to compromise 
risk, return and the value of compound interest, as well as the need for explanations of the pros and cons of certain types of investments.

- The presence of trained consumers can also be beneficial to the economy. By ordering products that better meet their needs, these consumers encourage providers to develop new services and products, thereby increasing competition on capital markets and improving quality and innovation. Financially educated consumers will be able to save even more than their less-educated counterparts. The increase in savings associated with the development of financial culture would have positive impacts on the level of investment and economic growth. In emerging economies, providing consumers with both information and training on how markets work and the role of market participants will help these countries to better benefit from the development of their markets. In addition, financially literate consumers will be better equipped to defend their interests and inform the authorities of any shortcomings in financial intermediaries. In this way, they facilitate the work of the supervisory authorities, which will in principle make it possible to reduce the frequency of their interventions. As a result, there should be fewer regulatory burdens on individual companies (Csiszarik-Kocsir, Varga, \& Fodor, 2016).

\subsection{Limitations to Financial Culture}

\subsubsection{Financial Dilemmas}

SMEs are facing financial problems associated with the complex financial environment. Wrong financial decisions due to lack of knowledge and wrong financial information can highly affect their global performance and their sustainability. Researchers have predicted that low-income people have the same behaviours, prejudices and attitudes as those who suffer from sudden, stressful personal situations. Similarly, it is difficult for people living in poverty to acquire the skills and capacity to change their financial conditions. This means that making an effective financial decision is not only affected by the individual's lack of skills and abilities, but also by the state of the environment around them (Reuter, 2011).

\subsubsection{Culture}

Following certain cultures will allow individuals to become financially literate, but the latter does not determine how others are affected by an individual's decision making. It is therefore important to highlight the influences of financial decision-making and how others are affected in accordance with the definition of financial culture, which includes cultural and personal values, socio-economic status, life stages, professional associations, level of education, and the media (Salazar, Soto, \& Espinosa, 2012).

\subsubsection{Qualification}

Financial education is a necessity to enable consumers to negotiate with their 
business advisors in a knowledgeable manner. It also allows them to take advantage of the information requirements to which they are increasingly subject. It must also be ensured, however, that financial advisors are qualified. To avoid this pitfall, it is necessary to develop regulations that gradually consolidate and regulate the information and advice obligations that financial institutions have towards individuals (Direr \& Visser, 2013).

\section{Research Methodology}

The research methodology refers to the set of steps that allow to search, identify and find documents related to a topic through the development of a search strategy. After the various theoretical and scientific researches on the issue of the effect of financial culture on SMEs' performance in Lebanon, we have adopted the quantitative study to solve the research problem.

The objective of a quantitative study is the collection of quantifiable and observable data. The aim of this type of research is to explain, control, describe and predict, based on the observation of events and facts.

This method is based on quantitative research techniques or instruments that allow for the collection of data whose validity and fidelity are theoretically assured. It produces encrypted data for tables and graphs, descriptive analyses, statistical analyses looking for links between factors or variables, association or correlation analyses.

\subsection{The Problem's Appearance}

The concept of financial culture shows its importance on SMIs' performance in terms of profitability and growth in order to succeed in providing the necessary financial skills and knowledge to manage risks, prevent bankruptcy and help the manager to make more appropriate and adequate financing decisions regarding the performance of his company (Agyei, 2018).

The theories and definitions already explained in the first part of the project also help in understanding the concept of financial culture, particularly the Organization for Economic Co-operation and Development (OECD) Council's definition, where financial education is defined as a process by which consumers/investors improve their knowledge, concepts of financial products and financial risks, in order to be as aware as possible of financial risks and opportunities, make reasoned and well-informed choices, find or know about financial assistance, and take other effective initiatives to improve their financial well-being (OECD, 2005).

On the other hand, there are definitions of financial culture specifically for managers and businessmen. A financially literate owner-manager of an SME has been defined as a person who knows the most appropriate financing decisions for business performance at different stages of company growth; knows where to obtain the most appropriate products and services; and confidently interacts with suppliers of these products and services (Brown, Saunders, \& Beresford, 
2006). Entrepreneurs are faced with complex financial decisions to turn their businesses around, they make financial decisions in the form of savings, investment and retirement planning, so financial culture becomes crucial in business financing decisions and subsequent performance. Decisions made by SME owners need to be made with a certain level of expertise, which requires financial culture knowledge, behaviors and attitudes that will enhance the business's financial performance (Cumming \& Johan, 2017).

Thus, the primary objective is to represent answers around the relationship between the financial culture and the financial performance of SMEs in Lebanon, which makes us faced with two hypotheses:

H1: There is a relationship between the financial culture and the financial performance of SMEs in Lebanon.

H0: There is no relationship between the financial culture and the financial performance of SMEs in Lebanon.

In addition, and as a sample, we have selected employees and managers of SMEs in various regions of Lebanon.

Based on the literature review, we propose to explain "What is the influence of financial culture on the financial performance of SMEs in Lebanon?".

\subsection{Research Design}

There are 3 main methods: deductive, inductive, hypothetico deductive. For this research work, we used the hypothetico deductive method which is designed to test the propositions, or hypothesis, on which the deduction is based, rather than to produce the result of the deduction (Brooks, 2018). It consists of 6 steps:

1) Research question.

2) Research method.

3) Conceptual framework.

4) Hypothesis formulation.

5) Data collection.

6) Data analysis.

\subsection{The Sample and the Questionnaire}

A sample of a certain population represents a subset of that population; a very small portion of that population that the researcher feels is satisfactory to help him or her solve his or her research. The aim of our research is to interview this sample in order to collect the necessary information and this procedure is done because it serves to reduce the cost of research and rather to save time.

First of all, the reference population (mother population) is chosen; this is the population to which one wishes to refer and which contains the sample concerned.

Once the mother population has been selected, it is up to the researcher to define it as precisely as possible (number of people, gender distribution, personal and professional characteristics, etc.). These criteria depend of course on the 
type of person concerned (student, teacher, parent, head teacher) and especially on the research's objective.

A survey applies, in statistics to conclusions taken from a population. In market research, sample size is used and determines the number of subjects that should be included in a study. Having the right sample size is crucial for finding a result which is statistically relevant.

Necessary Sample Size $=(\text { Z-score })^{2} * \operatorname{StdDev} *(1-\operatorname{StdDev}) /(\text { margin of error })^{2}$

With a confidence level of $90 \%$ and $9 \%$ margin of error, the ideal sample size is 84 according to Qualtrics sample calculator. Based on that, our questionnaire was distributed to 80 people (employees and managers) who we believe are sufficient to help with this research.

For this project, we proceeded to the quantitative data collection "questionnaire survey".

The questionnaire is a methodical search for information, i.e. an instrument for recording and storing information collected from respondents based on a set of questions (closed or open) asked by the researcher while awaiting the answers of the respondents that help him/her to solve his/her research and to arrive at clear solutions to his/her problem. The questionnaire is the link between the two participants in this research and study: the "interviewer" who administers the questionnaire to the respondents while establishing a trust relationship during communication, and finally, the "respondent" who is responsible for answering the questions and providing the most accurate information possible.

The main objective is to communicate scientific concerns about the subject correctly and unambiguously (Jenny, 2014).

About the written questionnaire, it was distributed to a sample of 80 people who could help us test the hypotheses while answering the 10 questions asked. This questionnaire consists of 3 consecutive parts:

The first part consists of 6 questions aimed at collecting rather personal information on the respondents by presenting their profile (sex, age, professional category, date of creation of the company, legal status and current workforce of the company).

The second part of the questionnaire consists of 3 questions concerning financial culture and its level in the company presented in the form of $3 \mathrm{Li}$ kert-scale questions.

The third part of the questionnaire consists of a Likert-scale question designed to complete the topic of corporate performance.

\section{Analysis and Results Discussion}

\subsection{Questionnaire Analysis and Interpretation}

Answers have been analyzed by SPSS and the results of the analysis are as follow.

\subsubsection{One Factor Descriptive Analysis}

Let's look at the descriptive statistics first. We see that the study was conducted 
with 80 people.

A mean can be defined as a calculation tool that summarizes a list of numerical values into a single real number, regardless of the order in which the list was created. The default one is the arithmetic mean, calculated as the sum of the terms in the list divided by the number of terms.

The standard deviation is a number used to indicate how the measurements of a group are distributed with respect to the mean or the expected value. In other words, the standard deviation is a measure of the dispersion of values in a statistical sample. A low standard deviation means that most of the numbers are close to the mean, a high standard deviation means that the numbers are more scattered.

1) Gender

As shown in Figure 1, the percentage of women (58.75\%) responding to the questionnaire is greater than that of men $(41.25 \%)$. The role of female contribution became important, enabling women empowerment and self-satisfaction.

2) Age

We can notice in Figure 2 that the percentage of the interval (26 - 40) is $58.75 \%$ which is the hight, followed by $(18-25)$ for $26.25 \%$, which means that the majority of respondents are youth and adults. The lowest percentage goes for people over 61 years old for $1.25 \%$, it could be explained by shifting the business management to their family members, especially that most of Lebanese SMEs' are family businesses (El-Chaarani \& El-Abiad, 2019).

3) Professional Category

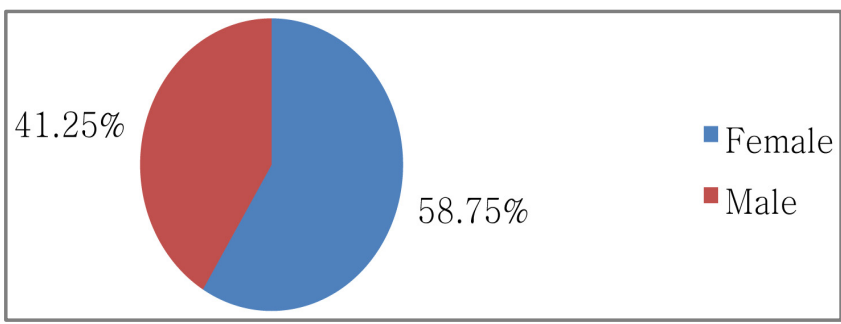

Figure 1. Gender pie chart.

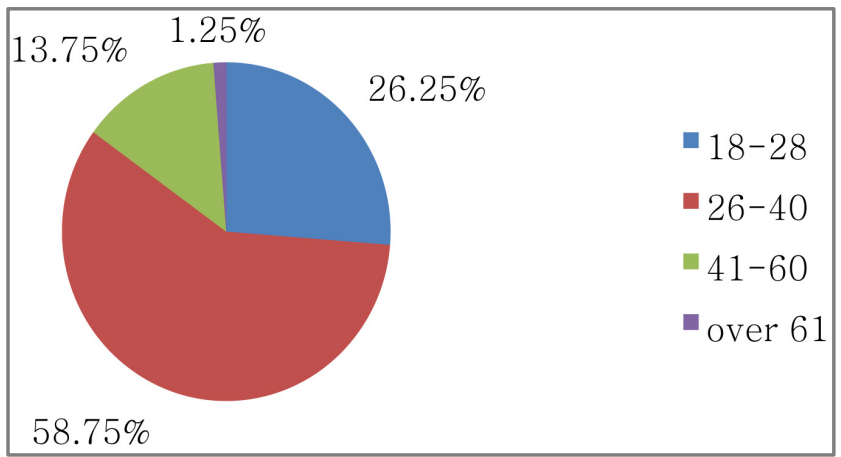

Figure 2. Age pie chart. 
According to Figure 3, we can notice that the percentage of employees (85\%) responding to the questionnaire is higher than that of supervisors (12.50\%) and managers $(2.50 \%)$. This shows that most of the respondents are employees.

4) Creation date

As shown in Figure 4, 62.34\% of SMEs' were created before 2005, supporting the previous idea of family business. When we say family business, we think long term business.

5) Legal Status

According to Figure 5, we can notice that the percentage of companies whose legal status is LLC (limited liability company,) presents (82.50\%). This shows that it is the most widespread medium-size type of company in Lebanon where the liability of the partners is limited to the amount of their contributions.

6) Staffing

As shown in Figure 6, the number of employees shows that the majority of

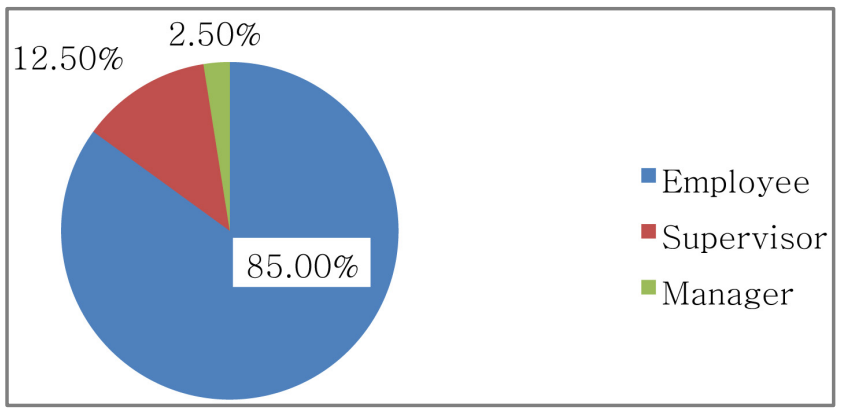

Figure 3. Professional category pie chart.

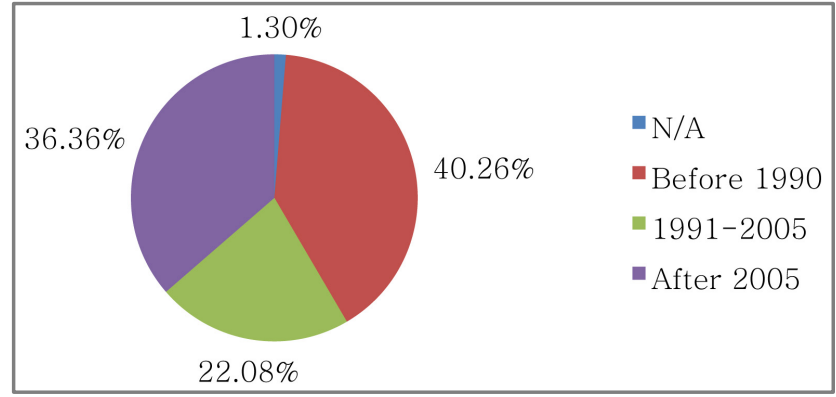

Figure 4. Creation date pie chart.

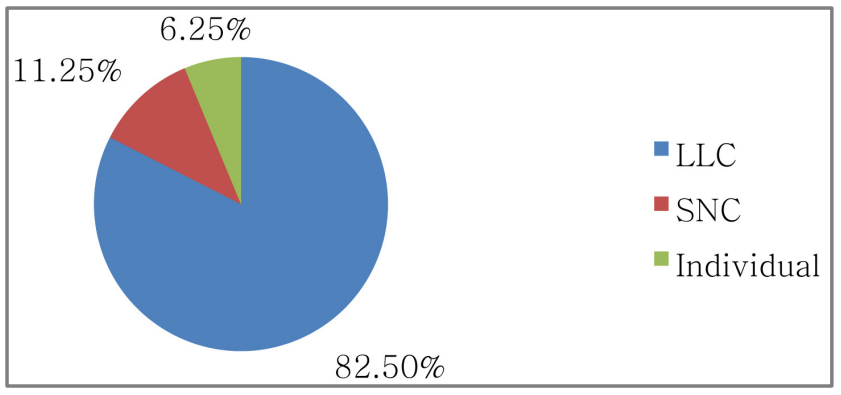

Figure 5. Legal status pie chart. 


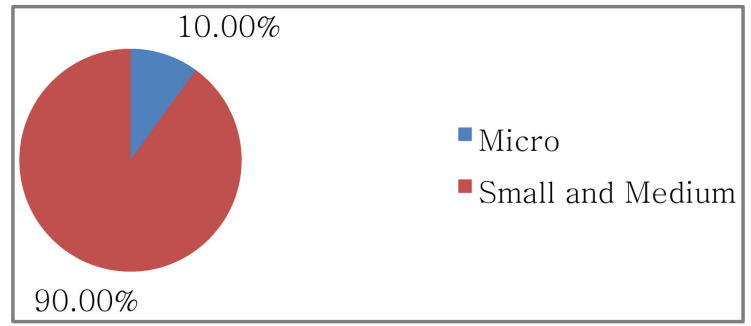

Figure 6. Staffing pie chart.

companies are small and medium-sized (90\%), which verifies the legal status of medium-sized limited liability companies.

7) Cronbach analysis

As shown in Table 1, the Cronbach alpha coefficient is a psychometric statistic to measure the internal consistency or reliability (internal validity) of the questions asked in a test. Its value is between 0 and 1 , being considered acceptable starting from 0.7 .

Its formula is calculated by $\alpha=\frac{K r}{1+(K-1) \bar{r}}$ where $K$ is the number of items and $\bar{r}$ the average correlation between items.

In this test, we have Alpha Cronbach which is equal to $0.788>0.7$, meaning an acceptable and validated result.

\subsubsection{Likert Analysis}

As shown in Table 2, the distribution through the Likert scale can be explained as follow: as the variables designating the choices are ordinal and the incoming numbers reflect the weights (no of course $=5$, no $=4$, maybe $=3$, yes of course $=$ 2 , yes $=1)$, then we calculate the mean $0.8(4 / 5)$ where 4 is the number of distances (from 1 to 2 , from 2 to 3 , from 3 to 4 , from 4 to 5 ) and 5 is the number of modalities (strongly agree, agree, somewhat agree, disagree, strongly disagree), which gives the following distribution:

1) Basic knowledge of financial concepts

The financial culture includes 8 factors treated separately: financial knowledge, financial culture, financial decisions, financial advice, training programs, inflation, money \& risks.

According to the Likert scale represented in Table 3, the average of each financial culture question is calculated to reach an overall average of 4.02 i.e. yes. This means that respondents confirm their awareness of the concepts of financial knowledge.

2) Knowledge of financial products

The Financial products treated are: credit card, prepaid payment, leasing, current account, saving account, investment account, mirco finance loan, shares and units, bonds and insurance products.

As shown in Table 4, the means of each question of the financial products gives an overall mean of 4.211 , i.e. yes of course. This means that respondents 
Table 1. Alpha Cronbach on variables.

\begin{tabular}{cc}
\hline Alpha Cronbach & Number of variables \\
\hline 0.788 & 23 \\
\hline
\end{tabular}

Table 2. Means and their levels according to Likert.

\begin{tabular}{ccc}
\hline Mean & Level \\
1 & $\rightarrow 1.79$ & No of course \\
$1.8 \rightarrow 2.59$ & No \\
$2.6 \rightarrow 3.39$ & Maybe \\
$3.4 \rightarrow 4.19$ & Yes \\
$4.2 \rightarrow 5$ & Yes of course \\
\hline
\end{tabular}

Table 3. Likert analysis on the financial culture section.

\begin{tabular}{cccccccccc}
\hline Labels & Scale & $\begin{array}{c}\text { Yes of } \\
\text { course }\end{array}$ & Yes & Maybe & No & $\begin{array}{c}\text { No of } \\
\text { course }\end{array}$ & Mean & $\begin{array}{c}\text { Standard } \\
\text { deviation }\end{array}$ & Result \\
\hline $\begin{array}{c}\text { Financial } \\
\text { culture }\end{array}$ & $\mathrm{n}$ & 26 & 51 & 3 & 0 & 0 & 4.02 & 0.331 & Yes \\
\hline
\end{tabular}

Table 4. Likert analysis of the financial products section.

\begin{tabular}{|c|c|c|c|c|c|c|c|c|c|}
\hline Labels & Scale & $\begin{array}{l}\text { Yes of } \\
\text { course }\end{array}$ & Yes & Maybe & No & $\begin{array}{l}\text { No of } \\
\text { course }\end{array}$ & Mean & $\begin{array}{l}\text { Standard } \\
\text { deviation }\end{array}$ & Result \\
\hline \multirow{2}{*}{$\begin{array}{l}\text { Financial } \\
\text { products }\end{array}$} & $\mathrm{n}$ & 50 & 30 & 0 & 0 & 0 & \multirow{2}{*}{4.211} & \multirow{2}{*}{0.353} & \multirow{2}{*}{$\begin{array}{l}\text { Yes of } \\
\text { course }\end{array}$} \\
\hline & $\%$ & $62.5 \%$ & $37.5 \%$ & $0.0 \%$ & $0.0 \%$ & $0.0 \%$ & & & \\
\hline
\end{tabular}

acknowledge their knowledge of financial products.

3) Financial culture in general

Working on the financial culture it will be necessary to work on financial knowledge and financial products separately.

Based on Table 5, the means of each question of the financial culture gives an overall mean of 4.115 , i.e. yes. Interviewed persons acknowledge their awareness of financial culture.

4) Financial performance

The financial performance covers several treated points such as performance, decision, new product, profit and capacity.

Based on the Likert scale analysis displayed in Table 6, it can be said that there are acceptance and validation for an average of 3.88 .

\subsubsection{Correlation Analysis}

We are now studying the relationship between financial culture and SMEs' financial performance of SMEs.

We thus do the Pearson correlation test.

H0: There is no relationship between financial culture and SMEs' financial performance. 
Table 5. Likert analysis of the financial culture section.

\begin{tabular}{cccccccccc}
\hline Labels & Scale & $\begin{array}{c}\text { Yes of } \\
\text { course }\end{array}$ & Yes & Maybe & No & $\begin{array}{c}\text { No of } \\
\text { course }\end{array}$ & Mean & $\begin{array}{c}\text { Standard } \\
\text { deviation }\end{array}$ & Result \\
\hline $\begin{array}{c}\text { Financial } \\
\text { culture }\end{array}$ & $\mathrm{n}$ & 30 & 49 & 1 & 0 & 0 & 4.115 & 0.222 & Yes \\
\hline
\end{tabular}

Table 6. Likert analysis of the performance section.

\begin{tabular}{|c|c|c|c|c|c|c|c|c|c|}
\hline Labels & Scale & $\begin{array}{l}\text { Yes of } \\
\text { course }\end{array}$ & Yes & Maybe & No & $\begin{array}{l}\text { No of } \\
\text { course }\end{array}$ & Mean & $\begin{array}{l}\text { Standard } \\
\text { deviation }\end{array}$ & Result \\
\hline \multirow{2}{*}{ Performance } & $\mathrm{n}$ & 10 & 66 & 4 & 0 & 0 & \multirow{2}{*}{3.88} & \multirow{2}{*}{0.277} & \multirow{2}{*}{ Yes } \\
\hline & $\%$ & $12.5 \%$ & $82.5 \%$ & $5.0 \%$ & $0.0 \%$ & $0.0 \%$ & & & \\
\hline
\end{tabular}

H1: There is a relationship between financial culture and SMEs' financial performance.

According to Table 7, we notice that the significance size is equal to $0.000<$ 0.05 which means that there is a strong relationship between financial culture and financial performance of SMEs with a high proportional correlation of $79.1 \%$. This rejects the null hypothesis and accepts the alternative hypothesis, meaning there is a relationship between financial culture and the financial performance of SMEs.

\subsection{Impact Deduction}

\subsubsection{The Importance of SMEs in Lebanon}

Both in developing and developed countries, SMEs play an important role. Indeed, Lebanon is considered as an emerging country, is characterized by an entrepreneurial dynamism where SMEs represent the strength of its economy (Malaeb, 2018). However, SMEs in Lebanon participate in the creation of added value and represent $97 \%$ of all enterprises, employ half of the country's working population and produce $70 \%$ of the national wealth. Between the years 2005 and 2010, micro start-ups created 60,000 jobs in Lebanon while new large companies created only 12,000 jobs. The only problem is that in Lebanon, the average lifespan of an SME is 5 years. One of the reasons for this is that there is not yet an official definition of who is and who is not a sme, which makes it difficult to create and develop policies to support their development.

\subsubsection{Financial Culture in Lebanon}

Financial and economic literacy and its impact on stability and growth around the world, as in the region and in Lebanon, was the key topic of an international conference held in Beirut by the OECD and the BDL. On this occasion, the Governor of the Central Bank, as well as the then Ex-Minister of Finance, Raya El-Hassan, called for a national strategy to promote financial culture in Lebanon.

Building a futuristic society with advanced economic and financial knowledge reflects the important role played by financial culture. Focused on this importance, the conference, the first of its kind in the Middle East, brought together 
Table 7. Correlation test results.

\begin{tabular}{cccc}
\hline \multicolumn{3}{c}{ Correlations } \\
\hline & Financial culture & Financial performance \\
\hline \multirow{2}{*}{ Financial culture } & Pearson Correlation & 1 & $0.791^{* *}$ \\
& Sig. (2-tailed) & & 0.000 \\
& $\mathrm{~N}$ & 80 & 80 \\
Financial performance & Pearson Correlation & $0.791^{* *}$ & 1 \\
& Sig. (2-tailed) & 0.000 & 80 \\
\hline
\end{tabular}

${ }^{*}$ Correlation is significant at the 0.01 level (2-tailed).

experts and officials from more than 40 countries to explore ways to resist financial literacy in times of great upheaval.

In this respect, André Labour, Head of the Financial Affairs Division of the OECD, regretted the high level of financial literacy around the world, particularly in some regions, while stressing the need to promote financial culture to consolidate good governance, making markets more efficient and leading to greater social cohesion, especially in the context of growing financial risks. Thus, there is a need for greater awareness of the economic challenges and dangers facing citizens in order to reduce the degree of vulnerability.

The same is true of the Lebanese stakeholders, mentioned the Ex-Minister of Finance, Raya El-Hassan. In her speech, she stressed the long-term positive impact that "training enlightened young people on the main economic options made at the national level" can have. At the same time, the Ex-Minister revealed the launch of a project to assess the level of economic and financial knowledge of citizens at the national level, while proposing the creation of a high committee to promote financial and economic culture through the establishment of information campaigns and programmes aimed at different components of the population. A draft decree establishing this body will be submitted to the Council of Ministers in order to develop a national strategy for the promotion of economic and financial culture in Lebanon, in cooperation with all the institutions concerned.

In the same spirit, the General Director of the Ministry of Education and Higher Education, Fadi Yarak, for his part, stressed his ministry's commitment to promoting financial culture in schools and universities, referring to "the establishment of a training programme for all economics teachers in public schools, in cooperation with the Ministry of Finance and the Institute of Finance".

As for the Governor of the Banque du Liban (BDL), Riad Salamé, he welcomed the efforts made since 2003 by the OECD to spread financial culture around the world, stressing the great importance of financial education in consolidating the role of supervisory authorities, especially in the wake of the international crisis. Turning to the specific case of Lebanon, which he described as a 
regional center for the knowledge economy, and the role played by the Central Bank in promoting financial culture, Mr. Salamé recalled the integrity of the various activities undertaken by the Training and Development Institute, and the establishment in 2008 of a financial protection and awareness unit. The BDL has launched three diplomas, in cooperation with the British Chartered Institute for Securities and Investments and the Ecole Supérieure des Affaires (ESA), aimed at promoting meritocracy in the banking sector. As a result, banks in Lebanon have also organized similar financial culture programs aimed at introducing the general public to the main economic and financial terms and concepts that are at the heart of their daily lives.

Still speaking of this initiative, let's take the role that Byblos Bank has played in helping to create financial culture programs such as the "fakker maliyan" initiative that dispels key concepts and topics related to the operation of financial products, "nes $\mathrm{w}$ finance" providing an overview and analysis of key aspects of personal finance, investment products and budgeting and broader economic issues. Similarly, Byblos Bank is taking its financial culture message to Lebanese youth directly through the organization of a series of Money Smart Boot Camps that provide and explain information related to the fundamentals of a healthy currency cycle, as well as how to make more informed decisions about managing their finances and planning for their future (Byblos Bank, 2020).

Byblos Bank conducted a survey taken by Lebanon This week, showing the financial rating agency Standard and Poor's (S\&P) on financial culture in different countries. According to this survey, $44.4 \%$ of Lebanese adults have basic financial knowledge. This level is considered above the world average of 33\%, with Norway ranked first (71.3\%) and Yemen last (13.3\%). This performance ranks Lebanon 33rd out of 144 countries around the world, and third out of 17 countries in the Mena region. The survey reveals that the level of financial culture in Lebanon does not vary much between the poorest and wealthiest households. To measure their level of knowledge, S\&P asked survey respondents about four concepts: interest rate, compound interest rate, inflation and diversification of investment risk. Those who were able to answer at least three questions correctly were seen as having "basic knowledge".

For another bank, Audi Bank has started to launch its yearly "learn.save.earn" financial culture programs during Global Money Week, educating students on the principles of financial culture and the basic concepts for building it among students.

In addition to all efforts of commercial banks in Lebanon, there are initiatives from public institutes such as the Basil Fuleihan Institute of Finance, a training and documentation center of the Ministry of Finance that devotes a large part of its activities to young people through awareness raising initiatives, financial and economic education through various programs and a series of booklets published under the name "Habib aaref aktar" highlighting the basic information that each individual needs to know. This manual illustrates the information in a 
comic way that the reader, especially young people, can better understand it and thus absorb its knowledge. FLI (Financial culture institute) is an NGO dedicated to increasing financial culture and improving the financial knowledge of all Lebanese citizens, including students, consumers and children, through awareness campaigns, seminars and workshops, as well as news and publications, all of which aiming at empowering citizens to make better financial decisions. Injaz Lebanon is a non-profit organization that aims at educating Lebanese youth and preparing them to become successful and skilled entrepreneurs and employees by implementing educational programs focusing on work readiness, entrepreneurship and financial culture.

\subsubsection{Deducing the Influence of Financial Culture on the Financial Performance of SMEs in Lebanon}

The study aimed at examining the effect of financial culture on SMEs' financial performance in Lebanon; more specifically, the study examined the effect of the level of financial culture on SMEs' profitability and financial performance.

80 persons (employees and managers) from about 20 SMEs in the various Lebanese regions were surveyed. The primary data were obtained by administering the questionnaire, tests were conducted (descriptive statistics, Alpha Cronbach, Likert and correlation) and the results established that the financial culture score has a positive effect on the performance of SMEs based on their positive Pearson coefficients (0.791), which shows that there is a proportional relationship between $\mathrm{X}$ and $\mathrm{Y}$ ( $\mathrm{X}=$ financial culture, $\mathrm{Y}=$ financial performance), a strong one indeed as 0.791 is between 0.5 and 0.8 .

With a significant effect on financial performance due to its low $p$-value of $0.000<0.05$, the null hypothesis is therefore rejected and it can be concluded that a correlation between $\mathrm{X}$ and $\mathrm{Y}$ exists.

This highlights the importance of possessing financial knowledge and having an adequate financial culture to be applied among all the company's executives. Since Lebanese SMEs represent the majority of the industrial and economic sector and achieve a high level of economic growth, making them a target or even essential element to increase their financial culture in order to increase their profitability and performance. Financial literacy will help businessmen take smart decisions, enhance their knowledge about credits and debts, manage expenses or take proactive steps to meet short-term and long-term needs, and therefore have a much lower probability of involuntary business closures. It is therefore necessary to acquire financial skills and apply this knowledge to the business (Lusardi, 2019).

\section{Conclusion}

The performance of SMEs poses critical problems and many studies have addressed the subject from several angles. The current study addresses one of the important issues: financial culture is a particular problem for small and medium-sized enterprises, as these latter tend to have much higher employment 
growth rates, but are also more likely to fail or lag behind in growth due to a lack of financial culture (Mitchell \& Abusheva, 2016).

Financial culture is a key life skill and is a political priority in some countries. Tightening social protection systems, demographic change and the sophistication and expansion of financial services all contribute to highlighting the importance of financial culture among citizens and consumers of all ages.

Similarly, financial culture has proven to be essential in stimulating both the financial and SME sectors, two important sectors that play an essential role in the development process of the economies of developing countries. The benefits of improved financial culture can be great. SMEs can save more money and have better risk management by purchasing insurance. There may even be general equilibrium effects: increased demand for financial services by enterprises may improve risk sharing, reduce economic instability, improve intermediation and accelerate overall financial development. This, in return, could facilitate competition in the financial services sector and ultimately lead to a more efficient allocation of capital within the company.

This study aims to determine the effect of financial culture on the financial performance of SMEs in Lebanon. The results of the study showed that the financial knowledge of SME owners is very important in explaining the use of financial services by SMEs. The survey we conducted gave a Pearson correlation coefficient of 0.791 and a $p$ of 0.000 which shows that there is a strong relationship between financial culture and the financial performance of SMEs in Lebanon.

In Lebanon, there is no fixed limit for the classification of SMEs, which are generally considered small with fewer than five workers and less than fifty workers, and medium between ten and one hundred workers. In both cases, the size of Lebanese institutions remains almost the same, given that their vast majority is very small and even individual. Yet Lebanon hosts two hundred thousand companies (as of the end of 2008) of which $88 \%$ (i.e. 170,000) are SMEs. 132,000 of these SMEs are commercial enterprises, 30,000 are industrial and 8000 are agricultural. Therefore, the majority of SMEs contribute to performance growth, job creation and social progress, things which are considered to be determining factors for an economic growth formula.

As a result, and considering the importance of Lebanon's SMEs which constitute the essential engine of the Lebanese economic sector's development, it is important and even crucial to have a diffusion of the concept of financial culture in the enterprises, allowing for a better knowledge of financial products and services, something which helps to benefit from the opportunities offered by financial products and services based on their profitability and performance and finally to reach the managers to make efficient financial decisions and the employees to give customers appropriate financial advice and to prevent bankruptcy.

In addition, we illustrated the situation of financial culture in Lebanon and focused on financial institutions and the efforts of commercial banks in contri- 
buting to the dissemination of financial culture, which is also of high importance among SMEs that must have training programs or teams that deal with the popularization of financial culture.

Based on the Lebanese revolution of November $17^{\text {th }}, 2019$, the actual financial and economic crisis in the country, the dollarized economy, the black money exchange market, shortage in liquidity and the daily new financial regulations announced by the Central Bank, it could be an opportunity to complete this research by surveying SMEs with critical financial issues due to credits and banks limitations and how to survive in an unstable political, financial and economical situation.

\section{Conflicts of Interest}

The authors declare no conflicts of interest regarding the publication of this paper.

\section{References}

Agyei, S. (2018). Culture, Financial Literacy, and SME Performance in Ghana. Cogent Economics \& Finance, 6, 1-16. https://doi.org/10.1080/23322039.2018.1463813

Akhtar, S., \& Liu, Y. (2018). SME Managers and Financial Literacy; Does Financial Literacy Really Matter? Journal of Public Administration and Governance, 8, 353. https://doi.org/10.5296/jpag.v8i3.13539

Aren, S., \& Aydemir, S. (2014). A Literature Review on Financial Literacy. Finansal Araştırmalar ve Çalışmalar Dergisi, 11, 33-49. https://doi.org/10.14784/JFRS.2014117326

Basu, S. (2005). Discussion of "Conditional and Unconditional Conservatism: Concepts and Modeling”. Review of Accounting Studies, 10, 311-321. https://doi.org/10.1007/s11142-005-1533-5

Blackburn, R., Hart, M., \& Wainwright, T. (2013). Small Business Performance: Business, Strategy and Owner-Manager Characteristics. Journal of Small Business and Enterprise Development, 20, 8-27. https://doi.org/10.1108/14626001311298394

Brooks, D. (2018). Research Methodology \& Analysis Report.

Brown, R., Saunders, M., \& Beresford, R. (2006). You Owe It to Yourself: The Financially Literate Manager. Accounting Forum, 30, 179-191.

https://doi.org/10.1016/j.accfor.2006.03.001

Byblos Bank (2020). Financial Literacy. https://www.byblosbank.com/financial-literacy-lebanon

Calcagno, R., \& Monticone, C. (2013). Financial Literacy and the Demand for Financial Advice. SSRN Electronic Journal. https://doi.org/10.2139/ssrn.2336061

Csiszarik-Kocsir, A., Varga, J., \& Fodor, M. (2016). The Value Based Analysis of the Financial Culture. The Journal of MacroTrends in Social Science, 2, 89-100.

Cumming, D., \& Johan, S. (2017). The Problems with and Promise of Entrepreneurial Finance. Strategic Entrepreneurship Journal, 11, 357-370. https://doi.org/10.1002/sej.1265

Direr, A., \& Visser, M. (2013). Portfolio Choice and Financial Advice. Finance, 34, 35-64. https://doi.org/10.3917/fina.342.0035

El-Chaarani, H., \& El-Abiad, Z. (2019). Exploring the Financial Dimensions of Lebanese 
SMEs: Comparative Study between Family and Non-Family Business. International Review of Management and Marketing, 9, 19-30. https://doi.org/10.32479/irmm.7976

Freiling, J., \& Harima, J. (2019). Entrepreneurial Finance. In Entrepreneurship (pp. 295-340). Wiesbaden: Springer: Gabler. https://doi.org/10.1007/978-3-658-26117-7_14

Hilgert, M., Hogarth, J., \& Beverly, S. (2003). Household Financial Management: The Connection between Knowledge and Behavior. Federal Reserve Bulletin, 89, 309-322.

Jenny, R. (2014). Designing and Using Research Questionnaires. Management Research Review, 37, 308-330. https://doi.org/10.1108/MRR-02-2013-0027

Joo, S., \& Grable, J.E. (2004). An Exploratory Framework of the Determinants of Financial Satisfaction. Journal of Family and Economic Issues, 25, 25-50. https://doi.org/10.1023/B:JEEI.0000016722.37994.9f

Karadag, H. (2016). The Role of SMEs and Entrepreneurship on Economic Growth in Emerging Economies within the Post-Crisis Era: An Analysis from Turkey. Journal of Small Business and Entrepreneurship Development, 4, 22-31. https://doi.org/10.15640/jsbed.v4n1a3

Kimiyaghalam, F., \& Safari, M. (2015). Review Papers on Definition of Financial Literacy and Its Measurement. SEGi Review, 8, 81-94.

King, K., \& McGrath, S. (2002). Globalisation, Enterprise and Knowledge: Educational Training and Development. International Review of Education, 50, 74-76. https://doi.org/10.1023/B:REVI.0000018307.23287.74

Kofi, F., Nunoo, F., Asamoah, E., Yaw, \& Osei-Asare, Y. (2012). Economics of Aquaculture Production: A Case Study of Pond and Pen Culture in Southern Ghana. Aquaculture Research, 45, 1-14. https://doi.org/10.1111/are.12003

Lusardi A., \& Mitchell, O. S. (2011). Financial Literacy around the World: An Overview. Journal of Pension Economics and Finance, 10, 497-508. https://doi.org/10.1017/S1474747211000448

Lusardi, A. (2019). Financial Literacy and the Need for Financial Education: Evidence and Implications. Swiss Journal of Economics and Statistics, 155, 1-8. https://doi.org/10.1186/s41937-019-0027-5

Malaeb, O. (2018). Small and Medium Enterprises in Lebanon: Obstacles and Future Perspectives. Development Studies Series, Kuwait: Publisher Arab Planning Institute.

Matejun, M. (2014). The Role of Flexibility in Building the Competitiveness of Small and Medium Enterprises. Management, 18, 154-168. https://doi.org/10.2478/manment-2014-0012

Mitchell, J., \& Abusheva, M. (2016). The Actual Challenges of Financial Literacy. SHS Web of Conferences, 28, 01134. https://doi.org/10.1051/shsconf/20162801134

OECD (2005). Financial Education Project: Background and Implementation. http://www.oecd.org/daf/fin/financial-education/oecdfinancialeducationprojectbackgr oundandimplementation.htm

Reuter, C. H. J. (2011). A Survey of "Culture and Finance". Finance, 32, 75-152. https://doi.org/10.3917/fina.321.0075

Salazar, A., Soto, C., \& Espinosa, R. (2012). The Impact of Financial Decisions and Strategy on Small Business Competitiveness. Global Journal of Business Research, 6, 93-103.

Schmidt, O., Niwaha, M., \& Tumuramye, P. (2016). Financial Literacy and Development-Experimental Insights from Rural Micro- and Small Entrepreneurs (MSEs) in Western Uganda. International Journal of Development Research, 6, 6758-6764.

Shukla, A., \& Kukreja, M. (2014). A Study of Risk Management in Finance Sector. SSRN 
Electronic Journal. https://doi.org/10.2139/ssrn.2576131

Stolper, O., \& Walter, A. (2017). Financial Literacy, Financial Advice, and Financial Behavior. Journal of Business Economics, 87, 581-643.

https://doi.org/10.1007/s11573-017-0853-9

Tidor, A., Gelmereanu, C., Baru, P., \& Morar, L. (2012). Diagnosing Organizational Culture for SME Performance. Procedia Economics and Finance, 3, 710-715.

https://doi.org/10.1016/S2212-5671(12)00218-3

Wang, Y. (2016). What Are the Biggest Obstacles to Growth of SMEs in Developing Countries?-An Empirical Evidence from an Enterprise Survey. Borsa Istanbul Review, 16, 167-176. https://doi.org/10.1016/j.bir.2016.06.001

Worthington Jr., E., Lavelock, C., Witvliet, C., Rye, M., Tsang, J., \& Toussaint, L. (2015). Measures of Forgiveness. In G. J. Boyle, D. H. Saklofske, \& G. Matthews (Eds.), Measures of Personality and Social Psychological Constructs (pp. 474-502). Cambridge, MA: Academic Press. https://doi.org/10.1016/B978-0-12-386915-9.00017-6 